\section{Concerned over Survival of the Sharp-tailed Grouse}

\author{
Frank Baines, Saltcoats
}

I am still quite anxious for the survival of our provincial bird emblem of Saskatchewan - the Sharptailed Grouse. There can be no question about the great reduction in its numbers throughout this locality. I went to the last annual meeting of the Natural History Society, at Regina, from Yorkton by car with five other keen observers and no one saw a Sharp-tailed either going or coming, although conditions were ideal both ways. Two Ruffed Grouse and one cock Pheasant were seen.

On a 200 mile journey by car from Saltcoats to Kipling, Grenfell Wolseley, Ellisboro, Lemberg, Melville and Saltcoats, only one Sharptail was seen. This journey too was made in the fall, and again under ideal conditions.

There used to be dancing grounds on the farms of Bert Maddaford, Sec. 13, B. R. Middleton, Sec. 11, W. A. Baines, Sec. 2, R. A. Maddaford, Sec. 8, D. C. F. Baines, Sec. 20, W. A. Salisbury, Sec. 17, all of Twp 23, R. 3-w2nd. - but none of these are used now.

The habit of these birds of flying only a short distance, makes it quite possible for hunters to follow them by car. With several hunters to surround their position, some are bound to be shot. Then too, another of their habits - that of perching on trees, makes them very conspicuous. This again, makes them very vulnerable.

The Pinnated Grouse is gone from here, perhaps never to return, and possibly to extermination. The Carrier Pigeon, although once counted by millions is exterminated - and the Whooping Crane has not long to live. It is easily possible for our Provincial Bird Emblem to follow, if we keep on as we have been doing.

The very least we can do is to make a closed season for them next year. I hope it is not too late.

\section{Pine Grosbeaks}

Mary Brennan, R.R. 1, Leross, Sask. On "Camp Wilderness", over C.B.C. recently the commentator remarked that Pine Grosbeaks are very irregular in their appearance. If that is so, we must be among the lucky ones this winter, for they have been quite numerous here since early fall. Almost any day their clear, sweet whistle can be heard from the shelterbelt; or they can be identified by their indulating flight as they move from bluff to bluff. Very interesting is their habit of whistling while in flight. They come quite close to the house too. Last week, during the warm spell, the family had a real thrill when one lit on the honeysuckle bush, in full view, not six feet from the window. It was dressed in the full glory of its rosy color, and seemed almost incongruous against a snowy background. A few minutes later, the same bird was splashing and bathing in a little puddle of snow-water under a south window, not four feet from our delightful eyes. This was on February 5th, surely almost a record for outdoor bathing!

\section{A Strange Partnership}

J. E. Roy, Meadow Lake

"Have any of our Blue Jay readers ever discovered a Hungarian Partridge nesting with a duck? In May, 1953, my uncle, Mr. Steve West of Birsay, Saskatchewan, made the unusal discovery right in his own farm yard. A mallard duck flew up from her nest in the grass, 30 yords from the house, and upon reaching the nest, my uncle discovered four Mallard eggs and 16 partridge eggs. Two days later, when he again inspected the nest, he found the Hungarian partridge setting on the mixed clutches, and the duck was nowhere to be found. At no time did he see the two birds setting together.

He then made the decision to destroy the duck eggs and let the partridge have the nest to herself. A few days later, upon returning to the nest, he discovered that the Hungarian's clutch had increased to 23 . The duck was not seen again; and, to complete the story, the Hungarian hatched 22 youngsters. 